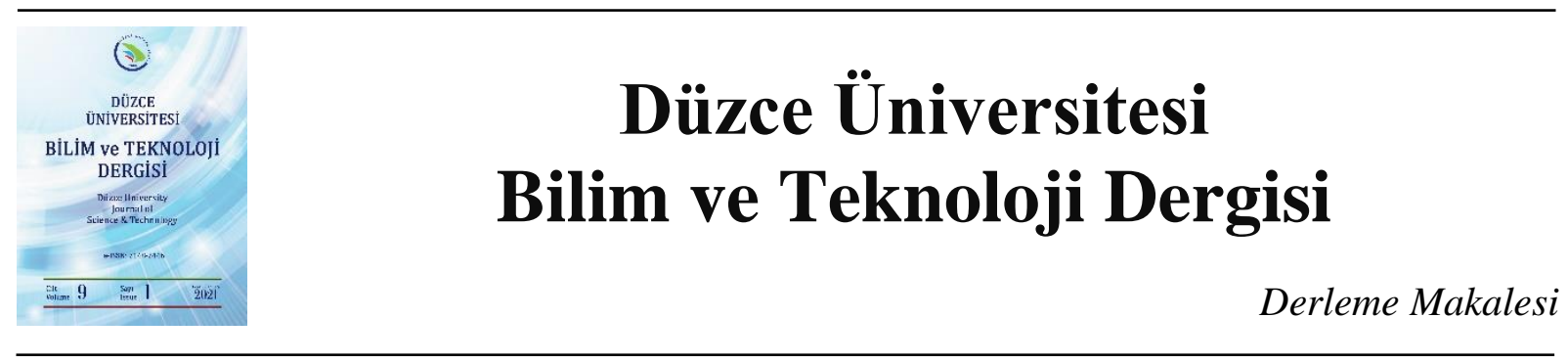

\title{
Mahalli İdare Birlikleri Bağlamında Sağlıklı Kentler Birliği Yerel Yönetimler İlişkileri: Bursa Örneği
}

\author{
(iD) Prof. Dr. Osman UZUN a , (D) Emine CAN ${ }^{\text {b* }}$ \\ ${ }^{a}$ Peyzaj Mimarlı̆̆ Bölümü, Orman Fakültesi, Düzce Üniversitesi, Düzce, TÜRKIYE \\ ${ }^{b}$ Peyzaj Mimarlı̆̆ Bölümü, Fen bilimleri Enstitüsü, Düzce Üniversitesi, Düzce, TÜRKIYYE \\ * Sorumlu yazarin e-posta adresi: eminecan.2828@gmail.com
}

DOI : 10.29130/dubited.786055

\begin{abstract}
ÖZET
Dünya genelinde gerçekleşen hızlı nüfus artışı ile kısıtlı olan doğal kaynakların modern yaşam tarzına yetmemesi, ya da yetmediği algısının olması kentlerin önde gelen sorunudur. Kentlerin sürdürülebilirliği geçmişten geleceğe uzanan koruma kullanma dengesinin sürdürülmesi ile mümkündür. Kentlerde meydana gelen ulaşım, trafik, iklim değişikliği, barınma, çarpık kentleşme, atık yönetimi vb. sorunların üstesinden gelinmesinde kullanılabilecek araçlardan birisi Sağlıklı Kentler Birliği kapsamında gerçekleştirilen bazı çalışmalardır.

Bu çalışmada yöntem olarak eko kent, yavaş şehir, dirençli kentler, akıllı kent ve sağlıklı kentler gibi sürdürülebilirliği temel alan bazı kentsel gelişim yaklaşımları araştırılmıştır. Dünya Sağlık Örgütü, Sağlıklı Kentler ve Türkiye'deki durumuna ilişkin irdelemeler yapılarak, Bursa kenti ve sağlıklı kentler kapsamında yapılan bazı projelerin incelenmesi gerçekleştirilmiştir. Sonuçta Sağlıklı Kentler birliğine üye belediyelerinin, sağlıklı kentler birliği açısından bazı sorun/faydaları ortaya konularak bazı öneriler getirilmiştir.
\end{abstract}

Anahtar Kelimeler: Sürdürülebilirlik, Să̆lıklı Kentler, Bursa

\section{Local Administration Associations, Local Governments Relationship of Healthy Cities Association and Application Examples}

\begin{abstract}
The inadequacy of natural resources for modern lifestyle, which is limited by the rapid population growth around the World, or the perception that it is not sufficient is the leading problem of cities. The sustainability of cities is possible by maintaining the balance of protection and use that extends from the past to the future. One of the tools that can be used to overcome the problems such as transportation, traffic, climate change, housing, unplanned urbanization, waste management etc. that occur in cities are some of the studies carried out within the scope of the Healthy Cities Association.

In this study, some urban development approaches based on sustainability such as eco-city, slow city, resilient cities, smart city and healthy cities are examined. The World Health Organization, the description is made on the situation examined in the Healthy Cities and Turkey, and the city was carried out to examine some of the projects carried out under healthy cities. As a result, some suggestions were made by putting forward some problems / benefits of the municipalities that are members of the Healthy Cities union in terms of healthy cities union.
\end{abstract}

Keywords: Sustainability, Healthy Cities, Bursa.

Geliş: 27/08/2020, Düzeltme: 22/12/2020, Kabul: 29/12/2020 


\section{GIRIS}

Yerel yönetimler, devlet tarafından verilen hizmetlerin merkezden icra edilmesinin zorluğu, hem ekonomik olmaması hem de hizmetin hızlı sunulması açısından oluşturulmuş kurumlardır. Yöre halkının yönetime katıldığı ilk evredir [30]. Yerel halkın ortak ihtiyaçlarını karşılamak, her türlü yerel hizmeti yerine getirmek, insan ayrımı yapmadan eşit imkânlar sunmak amacı ile kurulmuş kamu tüzel kişiliğinde olan demokratik yönetimlerdir [9]. On Birinci Kalkınma Planında ki tanıma göre ise, belirli bir coğrafi alanda yaşayan insan topluluğuna, bir arada yaşamaları nedeniyle onları en çok ilgilendiren konularda hizmet üretmek amacıyla kurulan, karar organları yöre halkınca seçilerek göreve getirilerek, yasalarla belirlenmiş görevlere, yetkilere, bütçeye ve personele sahip kamu tüzel kişileridir [24].

Yerel yönetim; bir kentte yaşayan insanların ve insan topluluğunun ortak ihtiyaçlarının karşılanmasına, ekonomik ve kültürel zenginliğine ve refahına ilişkin kamusal yerel işlerin, kendi sorumlulukları altında ve topluluğun yararları doğrultusunda düzenlenmesinde etkin kurumdur. İnsan yaşamıyla ilgili yerel ortamın ve koşulların; korunması, geliştirilmesi ve sürdürülebilir kılınması yerel yönetimlerin ilk sorumluluk alanında olmalıdır. Yerel yönetimler yapacakları kent planlarında, kentin ve kentte yaşayanların sağlığını sürdürülebilir kent planlamasıyla desteklemeli, kentlerin yaşanabilir sağlıklı ortamlar olmasını sağlamalıdır [7]. 03.07.2005 Tarih ve 25874 sayılı Resmi Gazete' deki, 5393 Sayılı Belediye Kanunu'nun 14. maddesinde: İmar, su ve kanalizasyon, ulaşım gibi kentsel alt yapı; Çevre ve çevre sağlı̆̆ı, temizlik ve katı atık; Zabıta, itfaiye, acil yardım, kurtarma ve ambulans; kent içi trafik; Ağaçlandırma, park ve yeşil alanlar; konut; kültür ve sanat, turizm ve tanıtım, gençlik ve spor; sosyal hizmet ve yardım" gibi görevler belediyelere verilmiştir [55].

5216 Büyükşehir Belediyesi Kanunu ile On dört İlde Büyükşehir Belediyesi ve Yirmi Yedi İlçe Kurulması ile Bazı Kanun ve Kanun Hükmünde Kararnamelerde değişiklik yapılmasına dair 6360 Sayılı Kanun 06/12/2012 tarih ve 28489 Sayılı Resmi Gazete' de yayımlanmıştır. 6360 sayılı Kanun ile Aydın, Balıkesir, Denizli, Hatay, Malatya, Manisa, Kahramanmaraş, Mardin, Muğla, Ordu, Tekirdağ, Trabzon, Şanlıurfa ve Van illerinde büyükşehir belediyesi kurulmuş, bu illerde mevcut il belediyeleri, büyükşehir belediyesine dönüştürülmüştür. Bu kanunla birlikte büyükş̧ehir belediyelerinin görev ve sorumluluk alanları il mülki sınırlara genişletilmiştir. Buna paralel olarak, belediye sınırlarında yaşayan nüfusun artması, belediye sayısının azalması, il özel idarelerinin büyükşehir belediyesi bulunan illerde tüzel kişiliklerinin kaldırılması gibi faktörler dikkate alınarak 15.07.2008 Tarih ve 26937 sayılı Resmi Gazete' de yayınlanan 5779 sayılı İl Özel İdarelerine ve Belediyelere Genel Bütçe Vergi Gelirlerinden Pay Verilmesi Hakkında Kanunda da değişiklikler yapılmıştır [56]. Yeni kurulanlarla birlikte büyükşehir belediyelerimizin sayısı 30'a ulaşmıştır. İl belediyesi bulunan 51 ilde ise il özel idarelerinin tüzel kişiliği devam etmektedir. 5355 sayılı yasa ile tek tek belediyelerin ve/veya diğer yerel yönetim birimlerinin yapamayacağı hizmetleri büyükşehir belediyeleri dışında mahalli idare birlikleri ile gerçekleştirilmenin olanaklı olacağı hedeflenmiştir. Bu yasa yerel yönetim birimleri arası işbirliğini tek hizmet temelli teşvik etmekte ve hukuken de güçlendirmektedir [29]. Yerel yönetimler kendi aralarında birlikler kurarak, kanunlarla verilmiş görevlerden bazılarını bu birlikler aracılığıyla gerçekleştirebilmektedir. Yerel yönetimlere birlik kurabilme yetkisi ilk olarak mülga 1580 sayılı Belediye Kanunu ile 1930 yılında verilmiştir. Köylerin kendi aralarında birlik kurmalarına ilişkin 442 sayılı Köy Kanunu'nda, köyler ile belediyelerin kendi aralarında birlik kurmalarına ilişkin 5442 sayılı İl İdaresi Kanunu'nda hükümler bulunmaktadır [24]. Birlik kurabilmek için 2/7/2018 tarihli ve 700 sayılı KHK'nin 166 ncı maddesiyle, bu maddenin birinci, ikinci ve üçüncü fikralarında yer alan "Bakanlar Kurulunun" ibareleri "Cumhurbaşkanının" şeklinde ve üçüncü fikrasında yer alan "Bakanlar Kurulu" ibaresi "Cumhurbaşkanı" şeklinde değiştirilmiştir ve Cumhurbaşkanından izin alınması gereklidir. ${ }^{1}$ Ayrıca, yerel yönetimler reformu kapsamında çıkarılan 5216 sayılı Büyükşehir Belediyesi Kanunu, 5302 sayılı İl Özel İdaresi Kanunu ve 5393 sayılı Belediye Kanunu'nda yerel yönetim birliği kurma veya kurulu bir birliğe katılma öngörülmektedir. Yerel yönetim birliklerinin yap1sı 26/05/2005 tarihli 5355 sayılı Mahalli İdare Birlikleri Kanunu ile düzenlenmiştir [24].

\footnotetext{
${ }^{1}$ https://www.mevzuat.gov.tr/mevzuat?MevzuatNo=5355\&MevzuatTur=1\&MevzuatTertip=5 (ET:10.12.2020)
} 
Mahalli idareler, büyüyen gelişen mekanlarda güçlerin birleştirilmesi ile kentsel ve kırsal hizmetlerin yerine getirilmesine kolaylık sağlayan, üyeliği isteğe bağlı olan tüzel kişiliktir [26]. Mahallî idare birlikleri ayrı bir yasaya bağlı olarak kendi kendini yönetme yetkisi olan yerel yönetim niteliğinde kamu kuruluşlarıdır. Birliğin meclis, encümen ve başkan olmak üzere üç organı vardır. Kanunda öngörülen istisnalar hariç mahalli idare birliği organları seçimle gelmektedir [39]. Mahalli idare birliği kurmak için en az iki mahalli idarenin bir araya gelmesi zorunlu iken, birlik kuracak mahalli idarenin aynı türde olması gerekmez. Örneğin; belediyeler kendi aralarında, il özel idareleri kendi aralarında ya da köyler kendi aralarında birlik kurabileceği gibi, belediye, il özel idaresi ve köyler birlikte kendi aralarında birlik kurabilirler [39]. Mahalli idare birliklerinin hukukî statüsünü, kuruluşunu, organlarını, yönetimini, görev, yetki ve sorumlulukları ile çalışma usul ve esasları 2005 yılında çıkarılan, 5355 Sayılı Mahalli İdare Birlikleri Kanunu ile tanımlanmıştır [39].

Yasaya göre ülkemizde kurulacak birlik türleri;

- Zorunlu birlikler,

- Ülke düzeyinde birlikler (Türkiye Belediyeler Birliği, Vilayetler Hizmet Birliği)

- Üye Sayısı Yüzden Fazla Olan Birlikler (Marmara Belediyeler Birliği, Eğe Belediyeler Birliği gibi)

- Köylere hizmet götürme birlikleri,

- Sulama birlikleri (2011 y1lında çıkarılan yasa ile Sulama Birlikleri Yerel Yönetim Birliği olmaktan çıkarılmıştır)

- Çevre ve alt yapı birlikleri,

- Turizm alt yapı birlikleri,

- Kalkınma birlikleri,

- Özel idare- belediye hizmet birlikleri,

- Diğer birlikler olarak belirtilmiştir [32].

5355 sayılı Mahalli İdare Birlikleri Kanunu her birliğin kuruluş amacını ve çalışma usullerini belirten bir ana tüzüğünün olmasını ve bu tüzükte aşağıdaki bilgilerin yer almasını öngörmektedir [40]. Birliğin adı, birliğin idari merkezi, arazi itibariyle faaliyet göstereceği alanın sınırları, sürekli olup olmadığı, geçici ise kaç y1l için kurulduğu, birliğe dahil olan idarelerin isimleri, birlik üyesi olan mahalli idarelerin hak, görev ve yetkilerinden hangileri birliğe ve birlik yönetme kurulana devir ve tevdi edildiği, birliğe dahil olan mahalli idarelerin her birinin birlik meclisi için seçeceği üye miktarı ve bu üye miktarının tespitine esas olan şartların kaç yılda bir birlik meclisi tarafından inceleneceği, birliğe dahil olan mahalli idarelerin birliğin kuruluş ve devam ettirilmesi giderlerine ne oranda katılacakları, birliğin gelirleri, birliğe dahil olan mahalli idarelerin ve bu mahalli idarelere bağlı halkın birlik müessese ve tesislerinden ne şekilde yararlanabilecekleri, birlik meclisinin yılda kaç kez toplanacağı, birliğin kuruluşuna ve faaliyetine esas olacak diğer şartlardır [32]. Bu yasa ile ülke düzeyinde yerel yönetim birliklerinin etkinliği artmış ve birlikler çoğalmıştır. Yerel yönetim birliklerinin gelişmesine katkı amacı ile yapılan bu yasal düzenleme olumlu sonuçlanmıştır. Yerel yönetim birlikleri, yerel yönetimlerin yetersiz kaldığ1 yerlerde, yerel yönetimlerin devrettiği yetkiler doğrultusunda yerel sorunların çözümünde aktif görev alan birliklerdir. Yerel yönetim birliklerinin yaygınlaşması ile yerel yönetim birimlerinin kendi aralarında kaynaşma sağlanacak, karşılıklı fikir paylaşımları oluşacaktır [32].

Mahalli İdare Birliklerinden birisi olan Sağlıklı kentler, sağlığı amaç edinmiş, huzurlu, yaşanabilir kent olmak için gerekli yapısal değiş̧iklikleri ve süreçleri başlatmak, çalışmaları bu yönde devam ettirmeyi hedefleyen bir kentsel gelişim aracıdır. Sağlıklı şehir, Sağlıklı Peyzaj, yapılı çevrenin bireylerin psikolojik, fizyolojik ve sosyal sağlığını nasıl etkileyebileceği ve daha sürdürülebilir şehirlere yol açabileceği ile ilgili bir kavramdır. Bu nedenle, Dünya Sağlık Örgütü tarafindan da önemsenerek uzun dönemde bir gelişim projesi olarak Sağliklı Kentler Projesi başlatılmıştır.1948'de Dünya Sağl1k Merkezi, sağlığı' tamamen fiziksel, zihinsel ve sosyal refah durumu' olarak tanımlamıştır. 1992'de Birleşmiş milletler, Çevre ve Kalkınma Rio Deklarasyonu'nun da ise kentlerin ve doğal kaynakların sürdürülebilir gelişimine dikkat çekilmiştir. Dolayısı ile "Sağlıklı Şehir ve Sağlıklı Peyzaj"' kavramları özellikle 2002 de yapılan Johannesburg Dünya Sürdürülebilir Kalkınma Zirvesi ve 2012'de yapılan Rio+20 zirveleri ile güncelliğini korumaktadır. Ayrıca sağlıklı kentler kavramının sürdürülebilir ve 
akıllı kentler kavramları ile de yakın ilişkileri bulunmaktadır. Ülkemizdeki 30 büyükşehir belediyesinin 17'si Sağlıklı Kentler Birliğine üye olmuştur. Mardin daha sonra birlikten ayrılmıştır. Güncelde Antalya Büyükşehir Belediyesi, Aydın Büyükşehir Belediyesi, Balıkesir Büyükşehir Belediyesi, Bursa Büyükşehir Belediyesi, Denizli Büyükşehir Belediyesi, Erzurum Büyükşehir Belediyesi, Hatay Büyükşehir Belediyesi, İstanbul Büyükşehir Belediyesi, İzmir Büyükşehir Belediyesi, Kahramanmaraş Büyükşehir Belediyesi, Kocaeli Büyükşehir Belediyesi, Mersin Büyükşehir Belediyesi, Muğla Büyükşehir Belediyesi, Ordu Büyükşehir Belediyesi, Samsun Büyükşehir Belediyesi, Trabzon Büyükşehir Belediyeleri Sağlıklı Kentler Birliği'ne (SKB) üyedir. Diğer üye olmayan büyükşehirlerin üye olmaması hem kentsel alanlara hem de kırsal alanlara hizmet götüren büyükş̧ehirler açısından önemli bir eksikliktir [57].

Bu çalışmanın amacı Sağlıklı Kent kavramından yola çıkılarak, dünyadaki ve ülkemizdeki sağlıklı kentler kavramının irdelenmesi, Sağlıklı Kent Planlama bakımından Türkiye'deki çalışmaların nasıl ilerlediği, Yerel Yönetimlerin çalışmalarına Sağlıkı Kentler Birliği çalışmalarının katkı ve etkisi, Bursa il örneğinde yapılan çalışmaların vurgulanarak değerlendirmelerin yapılmasıdır.

\section{MATERYAL VE YÖNTEM}

Araştırmanın materyalini, mahalli idareler ve sağlıklı kentlerle ilgili olarak yapılmış, literatür çalışmaları ile Bursa ilinde gerçekleştirilmiş projeler oluşturmaktadır.

Çalışmanın yöntemi birbirini izleyen 4 aşamadan oluşmaktadır.

1. Sürdürülebilirlik kavramı kapsamında bazı kentsel gelişim yaklaşımlarının irdelenmesi,

2. Dünya Sağlık Örgütü, Sağlıklı Kentler ve Ülkemizdeki durumuna ilişkin irdelemelerin yapılması,

3. Bursa kenti ve Sağlıklı Kentler kapsamında yapılan bazı projelerin irdelenmesi

4. Sağlıklı Kentler birliğine üye belediyelerinin, sağlıklı kentler birliği açısından bazı sorun/faydalarının ortaya konulmasidır.

\section{A. SÜRDÜRÜLEBİLİRLİK KAVRAMI KAPSAMINDA BAZI KENTSEL GELISSiIM YAKLAŞIMLARININ İRDELENMESI}

Sürdürülebilirlik; verimliliğin en uygun koşullarda uzun yıllar boyunca devamlılı̆̆ının sağlanması olarak tanımlanabilir. Doğal ve kültürel kaynaklardan en verimli şekilde yararlanmayı öngörmektedir. Kentlerin sürdürülebilirliği, toplumların sürdürülebilirliği olarak tanımlanabilir. İnsan toplulukları, yaşadıkları mekandan birebir etkilenmektedir. Kentlerin sürdürülebilirliğinin sağlanmasıyla; sadece yaşanan çevre sorunlarına çözüm getirmekle kalınmayıp, mevcut nüfusun yaşam kalitesinin artması ve gelecek nesillerin de yaşamlarını rahatlıkla sürdürebileceği yaşanabilir mekanların ortaya çıkması sağlanacaktır. Bu sayede, bugün ve gelecekte yaşanabilir kentler oluşturulması, insan-doğa-ekonomi üçgeninin en sağ lıklı şekilde kurulması sağlanacaktır [4]. Kentlerin sürdürülebilirliği, doğal kaynakların ölçülü kullanımı ile sağlanabilir. Akıllı, Ekolojik, Yavaş kentler gibi kavramlar sürdürülebilir sağlıklı kentlerin oluşumunda etkindir [17]. Bu bölümde bazı kentsel gelişim yaklaşımları kısaca açıklanacaktır.

\section{A. 1. Akıllı Kentler}

A Akıllı kentler konusu ile ilgili kabul görmüş net bir tanım olmamakla birlikte, şehirlerde yaşayan insanların ihtiyaç ve talepleri dikkate alınarak mevcut kaynakları kentli yararına olacak şekilde, bilgi ve iletişim teknolojilerinin bir arada kullanılmasıyla alışılmış hizmetlerin dışında daha aktif hale getirildiği yerdir [23]. Dünyada ve ülkemizde kentleşme hızla artarken, vatandaşlara rahat kaliteli yaşam oluşturmak için akıllı kent ve sürdürülebilir kentsel hizmetlere ilgi de artmaktadır. Kentlerin verimli yönetimi için akıllı kent kavramı önem arz etmektedir. Akıllı şehirler kavramı kentsel sorunların çözümünde çatı görevi gören ve önemi gittikçe artan kalıcı bir kavramdır. Dünya'da akıllı şehirlere bakıldığında şehirlerin farklı akıllı şehir alanlarında öne çıktığı görülmektedir: Londra-Yönetişim, 
Singapur-Ulaşım, Barselona-Ekonomi, Amsterdam-Çevre, Seul Altyapı, Paris-Girişimcilik, DubaiTrend Teknolojiler, Berlin-Enerji, Santander-Altyapı [42]. Aşağıda dünyadaki bazı kentlerdeki akı1lı kent önekleri verilmiştir. Uygulanan teknolojik çözümlerden en çok vurgulananlar; su yönetimi, temiz ve yenilenebilir enerji, akıllı trafik kontrolü, e-devlet, şehir içi hareketlilik, kablosuz internet erişilebilirliği ve atık yönetimi ile ilgili çözümler olarak sayılabilir [35] (Tablo 1).

Tablo 1. Dünyadaki bazı akıllı şehir örnekleri

\begin{tabular}{|c|c|}
\hline Kent & Akıllı kent uygulamaları \\
\hline Londra & $\begin{array}{l}\text { Londra'da akıllı kent uygulaması ile, herkesin bilgi ve iletişim teknolojilerine } \\
\text { erişebildiği, dijital uygulamalar ile internet ulaşımı kısıtlı olan kişi sayısını azaltmak } \\
\text { amaçlanmıştır [10]. }\end{array}$ \\
\hline Singapur & $\begin{array}{l}\text { Singapur akıllı kent ve akıllı toplum oluşturmada gelişmiş dijital alt yapıya destek } \\
\text { vermektedir. Lojistik ve taşıma, akıllı kentler ve akıllı belediyecilik hizmetleri, } \\
\text { sağlıkta kişiye özel hizmet verilmesi, eğitimde güvenlik gibi alanlarda başarı } \\
\text { amaçlanmıştır [22]. }\end{array}$ \\
\hline Newyork & $\begin{array}{l}\text { Trafikte aktif yönetim, bisikletle ulaşımda kolaylık için bisiklete özel erişim gibi } \\
\text { ulaşım uygulamaları yapılmıştır. Kentte yağmur suyu toplama ve kanalizasyon } \\
\text { taşkınlarına engel olmak için LinkNYC yeşil altyapı programı geliştirilmiştir [12]. }\end{array}$ \\
\hline Seul & $\begin{array}{l}\text { Bilgi ve iletişim teknolojilerinin kalitesini arttırmak için oluşturulmuş uygulamada } \\
\text { internet sitesi ile otobüs, metro, kültürel etkinlikler, iş olanakları, gayrimenkul } \\
\text { bilgileri, kamu hizmetleri, engelliler için imkanlar ve şehir hakkında genel bilgi elde } \\
\text { edilmektedir [10]. }\end{array}$ \\
\hline Barselona & $\begin{array}{l}\text { Şehirdeki yaşamı kolaylaştıracak bir portal oluşturulmuştur. Akıllı otobüs ağı, evinde } \\
\text { bakıma ihtiyacı olan yaşlı, engelli ve yardıma muhtaç vatandaşlar için telebakım } \\
\text { hizmetleri, elektrikli ulaşım araçları ile kaliteli sürdürülebilir ve konforlu ulaşım } \\
\text { sağlamak, kolay ücretsiz internet erişimi, motorlu trafiği azaltmak ve kısa süreli } \\
\text { yolculuklar için bisiklet kullanımı kolaylığı sağlamak [28]. }\end{array}$ \\
\hline Amsterdam & $\begin{array}{l}\text { Trafiklink ile bulunulan trafik ortamına müdahale etme ve trafik hakkında bilgi sahibi } \\
\text { olma, akıllı yaşam ile evlerde bilinçsiz enerji tüketimini engellemek ve bu konuda } \\
\text { bilinç oluşturmak, fuar alanlarında kullanılan akıllı alanlar, akıllı alt yapı projesi ile } \\
\text { fosil yakıtların tüketimini azaltmak ve enerjide maliyeti düşürmek [28]. }\end{array}$ \\
\hline Paris & $\begin{array}{l}\text { Paris Akıllı Şehir uygulamasında, temiz ve kolay ulaşım, yenilenebilir enerji proje } \\
\text { uygulaması, ulaşım ağının yenilenmesi, ilk bisikletli ulaşım görülmektedir [63]. }\end{array}$ \\
\hline San francisco & $\begin{array}{l}\text { Tasarlanmış akıllı sokak lambaları ile enerji tüketimi kontrol edilmekte ve harcanan } \\
\text { elektrikte tasarruf sağlanmaktadır [64]. }\end{array}$ \\
\hline Berlin & $\begin{array}{l}\text { Berlin Akıllı Şehir uygulamalarında amaç, daha sağlıklı ve temiz çevre, daha } \\
\text { sürdürülebilir ve yaşanabilir kent ortamı oluşturmaktır [64]. }\end{array}$ \\
\hline Dubai & $\begin{array}{l}\text { Dubai, akıllı yaşam, zeki insanlar, akıllı ekonomi, akıllı çevre ve yönetim, akıllı } \\
\text { mobilite amaçlamaktadır [66]. }\end{array}$ \\
\hline Santander & $\begin{array}{l}\text { Yenilenebilir enerji kaynaklarının enerji sektöründe kullanılması ve enerji yönetimi } \\
\text { konularını kapsayan uygulamasıdır [65]. }\end{array}$ \\
\hline Moskova & $\begin{array}{l}\text { Akıllı kent uygulamalarında enerji ve ulaşım konusunda çalışmalar bulunmakta ve } \\
\text { geliştirilmektedir [12]. }\end{array}$ \\
\hline
\end{tabular}

29 Aralık 2016 tarihinde İstanbul'da, "İstanbul Akı1lı Şehir Projesi Çevre Odak Alanı” olarak İlk çalıştay gerçekleştirilmiştir. Bu çalıştayda akıllı şehirler kapsamında kurum ve kuruluşların durum değerlendirmesi yapılmıştır [67]. 1-2 Ağustos 2017 tarihinde İstanbul'da Sürdürülebilir Akıllı Şehirler Çalıştayı düzenlenmiştir. Bu çalıştayda akıllı şehirciliğin öneminden, bu kavramı gerçekleştirmek için teknolojinin verimli etkin şekilde kullanılmasından, bütünleşmiş bakış açısı ile yapılabileceklerden bahsedilmiştir. Sürdürülebilir temel unsurlar incelenmiş olup bu unsurlar ile ilgili örnekler verilmiştir. Sürdürülebilirliği sağlarken elde edilen kazanımlar anlatılmıştır [61]. Ülkemizde akıllı kent uygulamalarında öne çıkan bazı örnekler Tablo 2 de verilmiştir. 
Tablo 2. Ülkemizde akıllı kent uygulamalarında öne çıkan bazı örnekler

\begin{tabular}{|c|c|}
\hline İstanbul & $\begin{array}{l}\text { Akıllı kent uygulamaları } \\
\text { Akıllı ulaşım sistemi, İstanbul kart, evsel atıkların depolanması ile elektrik enerjine } \\
\text { çevirme sistemi akıllı şehir uygulama örneklerindendir [3]. }\end{array}$ \\
\hline Ankara & $\begin{array}{l}\text { EGO, EGO cepte, akıllı durak, araç içi yolcu bilgilendirme ve kamera sistemleri, akıllı } \\
\text { yapılar, endüstri parkı, otomatik itfaiye komuta merkezi [31]. }\end{array}$ \\
\hline Antalya & $\begin{array}{l}\text { "Akıllı Şehir Antalya" mobil uygulaması, şehir bilgilendirme ekranları, akıllı şehir } \\
\text { yönetim platformu, güneş enerjisi santralleri, katı atık yönetim ve dönüşümü, akı1lı } \\
\text { aydınlatma ve sulama sistemi [31]. }\end{array}$ \\
\hline Bursa & $\begin{array}{l}\text { Kent meydanı tramvayda sinyalizasyon sistemi ile trafik kontrolü, otomatik kart } \\
\text { dolum ve bilet satış makinaları, gelişmiş internet ağı, sevgi çipi uygulaması, katı atık } \\
\text { enerji dönüşümü [50]. }\end{array}$ \\
\hline Gaziantep & $\begin{array}{l}\text { Akıllı Park ve Bahçe Sulama, Yenilenebilir Enerji Sistemler, ulaşımda planlamalar, } \\
\text { insan odaklı dönüşümler [43]. }\end{array}$ \\
\hline Kayseri & $\begin{array}{l}\text { “Akıllı Şehir Kayseri” mobil uygulaması, akıllı aydınlatma, akıllı sulama, trafik } \\
\text { kontrol merkezi, bisiklet yolu ve durağı, sürdürülebilir enerji sistemleri [49]. }\end{array}$ \\
\hline Kahramanmaraş & $\begin{array}{l}\text { Kent bilgi sistemi, Kahramanmaraş mobil uygulaması, mezarlık bilgi sistemi, akıllı } \\
\text { yaşlı bakım ve koordinasyon merkezi (manevi evlat butonu), akıllı kavşak } \\
\text { uygulaması, araç içi yolcu bilgilendirme, ulaşım yönetimi, afet koordinasyon sistemi } \\
\text { [35]. }\end{array}$ \\
\hline Konya & $\begin{array}{l}\text { Akıllı toplu ulaşım sistemi, akıllı durak ekranları, akıllı kavşaklar, toplu ulaşımda } \\
\text { temassız banka kartı kullanımı, bisiklet yolları, hava kirliliği izleme uygulaması } \\
\text { sistemi, mobil Mesnevi uygulaması [2]. }\end{array}$ \\
\hline
\end{tabular}

Bir şehirde uygulanan akıllı şehir çalışması başka bir şehirde farklı sonuç verebilir. Her kentin ihtiyacı ve koşullarına göre çalışma yapılmalıdır. 2014-2018 yıllarını kapsayan ve ülkemizin temel politika belgesi olan Onuncu Kalkınma Planında; 'Akıllı uygulamaların sağlık, eğitim ve öğretim, sosyal hizmetler, ulaştırma, bina, enerji ile afet ve su yönetimi gibi alanlar başta olmak üzere kullanımı yaygınlaştırılacaktır. ${ }^{2}$ On Birinci Kalkınma Planları İlkeleri ise, yerleşmiş sağlam ekonomi, üretimde rekabet ve verimlilik, kaliteli insan ve kuvvetli toplum, çevre sürdürülebilirliği ve yaşanabilir kentler, demokratik hukuk devleti ve başarılı yönetim. ${ }^{3}$ olarak sıralanmıştır. Şehirlerin yaşam kalitesini arttırmak için teknolojinin desteğine başvurulmaktadır. Şehirlerin bilgi ve iletişim teknolojileri alanındaki altyapı, kapasite ve beceri düzeyleri artırılarak akıllı kentlere dönüşmesi desteklenecektir' politikasına yer verilmektedir [17].

\section{A. 2. Ekolojik Kentler}

Ekolojik kent, bulunduğu çevreyi kirletmeyen koruyan, doğal kültürel ve tarihi değerlere zarar vermeyen, ekolojik ekonomik ve estetik İnsan, doğa ve kent arasında ilişki kurarak gelecek nesillere sağlıklı, temiz, sürdürülebilir şekilde oluşturulmuş yaşam alanlarıdır [16]. Günümüzde giderek artan çevre kirliliği ve doğa tahribatının bu kavram ile önlenmesi hedeflenmektedir. Kirleten kentler yerine kirletmeyen, doğaya saygılı ekolojik kent modelleri yaygınlaşmıştır. Ayrıca tahrip olmuş kentleri revize etme düşüncesi bu kavramı geliştirmiştir. Ekolojik ve ekonomik denge kurularak kentsel gelişme süreçleri sağlıklı ve yaşanabilir kentleri oluşturmalıdır [36]. Ekokent ilkeleri; İklime ve çevreye uyumlu hale getirilmesi, Çevre kirlenmesinin önlenmesi, Flora ve faunanın korunması, Su, hava ve toprak kirliliğinin önlenmesi, Su kaynaklarının verimli kullanılması, Atık suların geri dönüşümü, Yağmur suyunun kullanımı, Sera gazı emisyonlarının azaltılması, Fosil enerji kullanımının azaltılması, Yenilenebilir enerjinin kullanımı, Araba trafiğinin azalması, Çöplerin geri dönüşümünün sağlanması şeklinde tanımlanmaktadır [36]

\footnotetext{
${ }^{2}$ https://sbb.gov.tr/wp-content/uploads/2020/04/KentselYasamKalitesiOzelIhtisasKomisyonuRaporu.pdf (ET:12.12.2020)

${ }^{3}$ https://www.sbb.gov.tr/wp-content/uploads/2019/07/OnbirinciKalkinmaPlani.pdf (ET:12.12.2020)
} 
Sağlıklı kent planlamada enerjinin aktif kullanımı, ulaşımdaki iyileştirmeler ve ulaşımda kentli kullanımının kalitesinin arttırılması, toplu taşımaya teşvik edilmesi, yenilenebilir enerji kaynaklarının kullanımının arttırılması ve kullanma bilincinin oluşturulması, kentin planlamasında çevre düzenleme ve peyzaj tasarımı için şartlar geliştirilmesi gerekmektedir. Doğrudan veya dolaylı olarak insan, toprak, su, peyzaj, iklim, atmosfer, fauna ve flora ve kültürel miras üzerinde olumlu çalışmalar ile koruma kullanma dengesi gözetilerek sağlıklı sürdürülebilir kentler ilişkisi kurulabilir [25]. Kentsel mekânların doğal çevre üzerindeki baskısı ilk olarak kentlerde çevre bilinci oluşması, sağlıklaştırılması ve dönüştürülmesi gerekliliğini meydana getirmiştir. Kenti oluşturan kültürel değerler, endemik türler ve mevcut doğal kaynakların korunmasını amaçlayan eko-kent planlaması yapılmalıdır. Bu korumada doğal kaynakların kendini yenilemesine olanak sağlanalı, etkin ve verimli kullanım gerekmektedir. Ayrıca doğal kaynakların korunması ve çevre kirliliğinin önlenmesi için çıkarılmış yasal ve yönetsel düzenlemeler eko-kent planlamasının uygulanmasına destek olacaktır [21].

\section{A. 3. Sakin (Yavaş) Şehir}

Cittaslow (Sakin şehir) hareketi, şehirler birliği olan bu hareket, küçük kentlerin yerel özelliklerinin ortadan kaldırılmasını önlemek için planlama ve tasarımda kullanılması amaçlanan uluslararası bir ağdır [33]. Yalnızca nüfusu 50.000'den küçük yerel yönetimlerin tam üye olabildiği Cittaslow ağı günümüzde 28 ülkede 192 üyeye sahiptir [37]. 2019 itibariyle Türkiye'de 18 yavaş şehir üyesi bulunmaktadır. Ağa üye olan ilçeler şunlardır: Ahlat, Akyaka, Güdül, Gökçeada, Halfeti, Köyceğiz, Perşembe, Şavşat, Seferihisar, Taraklı, Uzundere, Yalvaç, Vize, Göynük, Mudurnu, Eğirdir, Gerze ve Yenipazar [37].

Günümüzde kentler markalaşırken kendi benliğini kaybedip tek tip kentler oluşmaktadır. Birbirlerinden, kendine has özellikleriyle yavaş şehir olgusuyla ayrılırlar. Kentin imajı, markalaşması, diğer kentlerden farkı bu kavramla gerçekleşir [44]. Kentlerin yerel ve özgün kimliklerinin korunması ve kentsel yaşam kalitesinin yükseltilmesi yavaş şehir hareketinin esas amacıdır. Kentte bozulmamış bir doğanın varlığı, koşuşturmanın olmaması, bisikletin ulaşımda daha fazla kullanıldığı, çevre kirliliğinin olmadığı, gürültü kirliliğinin olmadığı, gözü rahatsız eden dev yapıların bulunmadığı, sağlıklı gıda tüketiminin olduğu bir yer yavaş şehirdir. O şehirde yaşayan insanların sağlı̆̆ını etkileyecek dış çevresel etmenler yoktur. Barındırdığı insanı mutlu eder mağdur etmez. Yavaş şehir hareketi ile kaynaklarda iktisatlı kullanılıp sürdürülebilirlik sağlanır. Sağlıklı kent oluşumuna katkısı büyüktür [1].

Yavaş şehir hareketi küçük, daha çevreci kentleri bir araya getirmektedir. Yerel değerleri ön plana çıkarmak isteyen, metropollerden etkilenmemek için çaba gösteren küçük kentler açısından oluşmuş kalkınma modelidir. Hayatın herkes için kaliteli ve sağlıklı yaşanabilir olması, yerel kültürü ve gelenekleri desteklemek, teşvik etmek, yerel ekonomik yaşama katkı sağlamak, bölgesel değerlerle sürdürülebilir gelişmeyi sağlamak amaçlanmıştır. Yerel yönetim teşviki ile bölgede kalkınmaya destek olmaktadır ve istihdam oluşumuna katkı sağlamaktadır. Yerel üretimin korunması ve desteklenmesi, doğal çevrenin, tarihi eserlerin ve yapıların korunması, hayat kalitesinin artmasına ve yörede turizmin canlanmasına katkı oluşturmaktadır. Yavaş şehir hareketinin sağlayacağı kaliteli yaşam standartları ve yöredeki ekonomik hareketlilik ile bölge insanı büyük kentlere göç etmemiş olacaktır [44]. Ülkemizde sağlıklı kent üyesi olup aynı zamanda yavaş (sakin) şehir hareketini benimsemiş Aydın ilinin Yenipazar ilçesi vardır. Sağlıklı kent çalışmaları kapsamında merkez ve ilçelere gıda yardım kolisi hazırlanmıştır, ilçenin farklı yerlerine spor alanları(basket sahaları, yürüyüş yolları, bisiklet parkurları, tenis kortu gibi) kurularak halkın sağlığını artırmaya yönelik çalışma yapılmıştır [62].

\section{A. 4. Dirençli Kentler}

Dünyada doğal afetlerin artışı, iklim değişikliğinin olumsuz etkileri, fosil yakıtların kullanımının artması, plansız ulaşım ve altyapı dirençli kentler olgusunu ortaya çıkarmıştır [18]. Ülkemizde Onuncu Kalkınma Planında Dirençli Afet Yönetimi çerçevesinde çalışmalar oluşturulmuştur. Türkiye'de kentlerde nüfusun artışı ile afet risklerinin arttı̆̆ , dirençliliğin azaldığı görülmektedir. Kentlerde dirençliliği artırmak için ve planlanan çalışmalarda başarılı olmak için kamu ile beraber vatandaşların bu konuyu özümseyip bilinçli davranışlarda bulunulması esastır [47]. Dirençli şehirler, Birleşmiş 
Milletler'in Sürdürülebilir Kalkınma Hedefleri (SDG- Sustainable Development Goals) arasında da yer almaktadır. Hedef, yoksulların ve savunmasız durumda olanların iklim ile ilgili aşırı olaylara ve diğer ekonomik, sosyal ve çevresel şoklara ve felaketlere maruz kalma ve bunlara karşı savunmasızlıklarını azaltmak amacıyla direncin artırılmasıdır [46]. Dünyada dirençli kent örneği olarak Tokyo kenti verilebilir. İklimsel etkiler sonucu kentte birçok afet meydana gelmiştir. Bu kentte dirençli kent olma özellikleri gözlemlenmiştir [47].

\section{A. 5. Sağlıklı Kentler}

Sağlıklı bir kent sürekli olarak sosyal ve fiziksel çevreler yaratan, bunları geliştiren ve hayatın tüm fonksiyonlarını yerine getirebilme ve en yüksek potansiyellerine erişebilmeleri konusunda insanların birbirlerini desteklemesine olanak sağlayan, toplumsal kaynakları sürekli olarak genişleten kenttir [40]. Sağlıklı kent kavramı sosyoloji, kent coğrafyası, kent planlaması, çevrebilim, ekonomi, politika gibi birçok farklı disiplinleri içinde barındıran bir kavramdır. "Sağlıklı Kent" kavramı, her ülke, her kent, her kültür hatta aynı kentte yaşayan insanlar tarafindan bile farklı anlamlar ifade eder. "Sağlıklı Kent" kavramı içerisinde gelişmeleri, değişkenleri, ilişkileri, sektörleri, geleneksel öğeleri barındıran bir kavramdır [27]. Sağlıklı Kentlerde Amaç; Kentte önem arz eden tarihi değerleri yenilemek ve korumak, Kent içi ulaşımında rahat ve konfor sağlamak, Konut alanlarının planlanmasında ve yeşil alanların oluşturulmasında yeni fiziksel karakterler yaratmak, Kentte barınan insanlar arasında sosyal bütünleşmeyi sağlamak ve yaşanabilir yeni mekanlar oluşturmak amacı ile kuruluştur. Sağliklı şehir sağl1klı insan esası ile sürdürülebilirlik hedeflenmiştir [7]. Sürdürülebilirliği temel alan tüm bu kavramlara bakıldığında, yaklaşımların birbirlerinden etkilendikleri, insan konforunun kent içinde en iyi biçimde sağlanması için gerekli ilke ve amaçları içerdikleri görülmektedir.

\section{B. DÜNYA SAĞLIK ÖRGÜTÜ, SAĞLIKLI KENTLER VE ÜLKEMIZDEKİ DURUMU}

Dünya nüfusunun yarısından çoğu kentlerde yaşamakta ve pek çok sağlık sorunları bulunmaktadır. Kentlerde yaşayanlar, bulaşıcı hastalıklar, beslenme yetersizliği, ruhsal hastalıklar ve süreğen solunum yolu hastalıkları gibi çok çeşitli sağlık sorunlarına neden olan etkenlerle karşı karşıya kalmaktadır. Sağlıksız koşullarla birlikte, yoksulluk, yetersiz ve dengesiz beslenme, barınak, iş güvencesinin olmaması, atıkların sağlısız toplanması, güvenlik önlemleri, yetersiz iş ortamı, yerel yönetim hizmetlerinin yetersizliği, sağlığa zararlı madde kullanımı ve çevre kirliliğinin olması, yaşamı olumsuz etkilemektedir. Dünyadaki Sağlıklı Kentler Projesi'nin ilkeleri de bu çerçevede belirlenmiştir [Meriç E., 2006]. Sağlıklı Kentler Birliği 'Sürdürülebilir Kalkınma" ve 'Sürdürülebilir Kentler Yaratmak' için çok gerekli bir çalışma olarak adlandırılmaktadır ve yerel yönetimlerin gündemine sağlığı yerleştirmeyi hedeflemektedir [41].

Dünya Sağlık Örgütü (DSÖ), Birleşmiş Milletler tarafından 1948 yıılında kurulmuş, uluslararası sağl1k meseleleri ve halk sağlığ için hizmet veren bir kurumdur. İnsan sağlığ konusunda tarafsız ve güvenilir bilgi sunmak temel işlevleri arasındadır. Dünyadaki, 6 Dünya Sağlık Örgütü Bölge ofisinde, 194 ülkede, 220 Dünya kentinde ve 53 Avrupa kentinde 'Sağlıklı Kentler Hareketi' 'devam edip gelişmektedir [38]. Dünya Sağlık Örgütü (DSÖ) Projesi, Avrupa ölçeğinde sağllğ 1 , karar vericilerin gündeminde ön sıralara yerleştirmeyi ve herkes için sağlık stratejisinin prensipleri ve hedefleri doğrultusunda, sağlıklı ve sürdürülebilir bir kalkınma için kapsamlı yerel stratejiler geliştirmeyi amaçlayan uzun dönemli uluslararası bir gelişim çalışmasıdır. Sağlıklı şehirlerde tüm planların merkezine insanı yerleştirmek, projeleri hazırlarken ve uygularken insan odaklı olmasına önem vermek kentte barınan insanları mutlu etmektedir [45]. Sağlıklı Şehirler Projesi, 1987 yılından bu yana 5'er yıllık fazlar şeklinde farklı ana temalarda yürütülmüştür (Tablo 3). 
Tablo 3. Sağlıklı şehirler projesi aşamaları

\begin{tabular}{|c|c|}
\hline Aşamalar & Açıklama \\
\hline Projenin 1. Fazı & $\begin{array}{l}\text { 1987-1992 yılları arasını kapsamıştır. Bu faza Avrupa'dan } 35 \text { şehir katılmıştır. Amaç, } \\
\text { değişim rolü üstlenecek üyeler için yeni yapılar yaratmak ve şehir içerisinde sağlık } \\
\text { için çalışmanın yeni yollarını araştırmak ve sağlıklı bir kent için değişiklik } \\
\text { oluşturacak yapılanmaya gitmektir }{ }^{4} \text {. }\end{array}$ \\
\hline Projenin 2. Fazı & $\begin{array}{l}\text { 1993-1997 yılları arasında gerçekleşmiştir. } 39 \text { üye şehir bu fazda kent sağlığını } \\
\text { geliştirmek için çaba göstermiştir. Şehirler bu fazda halk sağlığı politikası ve kapsamlı } \\
\text { şehir sağlığ planlamasını ön plana çıkaran bir modelle harekete geçmişlerdir [14]. }\end{array}$ \\
\hline Projenin 3. Faz1 & $\begin{array}{l}\text { 1998-2002 yılları arasında sürmüştür. } \mathrm{Bu} \text { fazın ana temaları hakkaniyet, } \\
\text { sürdürülebilir kalkınma, sosyal gelişme, entegre sağlık gelişimi planları, sistematik } \\
\text { izleme ve geliştirme olarak belirlenmiştir. } 50 \text { şehir bu fazda yer almıştır. }\end{array}$ \\
\hline Projenin 4. Fazı & $\begin{array}{l}\text { 2003-2008 yıllarını kapsamıştır. Sağlıklı Şehirler hareketi bu fazda hızla yayılmıştır. } \\
\text { Aralarında Türkiye'den } 12 \text { şehrin de bulunduğu Avrupa'dan } 90 \text { şehir bu fazda üye } \\
\text { olmuşlardır. Dönemin ana temaları; sağlıklı kent planı ve sağlık etki }\end{array}$ \\
\hline
\end{tabular}

Sağlıklı kent kapsamında üye ülkelerden örnekler irdelendiğinde Kentsel Dönüşüm Uygulamalarında Dünyada başarılı Örnekler olarak Danbara (Hiroşima-Japonya), Solidere (Beyrut-Lübnan), Rio De Janeiro (Brezilya) şehirleri verilebilir. Brezilya'nın ikinci büyük kenti olan Rio De Janeiro insanlar iş bulmak ve daha iyi şartlarda yaşamak için kırsaldan göç etmişlerdir. Kırdan kente göç sonucu kentin nüfus ve konut sayısı artmıştır. Artan gecekondu sayısı bu bölgede altyapı, kanalizasyon, çöp sorunu gibi birçok etkene sebep olmuştur. Gecekondu alanlarının yeniden inşa edilmesi ile doğal dengenin korunması ve bölge insanının yaşam kalitesi artırılmıştır [5]. Danimarka'nın başkenti Kopenhag dünyanın en sağlıklı ve mutlu kentlerinden birisidir. Obezite ve depresyonun dünya genelindeki artışıla mücadele edebilecek bir kültür oluşturmayı hedeflemektedir [38]. Kopenhag, dünyada sağlıklı kentler oluşumuna en iyi örnek kenttir. Kent, Dünya Sağlık Örgütü'nün Sağliklı Kentler çalışmasına 1987'de katılmıştır.

Mark Reigelman tarafından 2007 yılında Brooklyn Borough Hall merdivenleri için tasarlanan küçük mavi masalar; insanların kamuya açık alanlarda dinlenmeleri, yeme ve okumaları için mükemmel ve şık bir çözüm sunmaktadır. ${ }^{5}$ Almanya Avrupa ülkeleri arasında fiziksel aktivite seviyesi en yüksek kent iken, İsviçre en düşük kenttir. Aktif yaşamı hareketlendirmek için insanların spor eğlence imkanlarına erişimlerini arttırmak hedeflenmektedir. Londra' da trafik sıkışıklığının ve bu sıkışıklığın oluşturduğu kazaların önüne geçebilmek için kent merkezine giriş ücrete tabi tutulmuştur. Bununla birlikte bölgede bisiklet kullanımı artmış, trafik kazalarında azalma gerçekleşmiştir. Çek Cumhuriyetinde 'Okulla Yürü' projesi ile yürümenin çevresel, eğitimsel, duygusal, fiziksel ve sağlığa katkıları vurgulanmıştır [11]. Başka bir örnekte ise yenilenebilir enerji potansiyeli bulunan kentler sağliklı kentler bakımından incelenmiştir. Dünyanın birçok kentinde Güneş Kent çalışması başlatılmıştır. (Adelaide)Avustralya, (Cape Town)Güney Afrika, (Daegu)Kore, (Oxford)İngiltere Güneş kent çalışması yapılmış örnek kentlerdendir [48].

Türkiye'de Sağlıklı Kentler Projesi çalışmaları 1993 yılında başlamıştır. Sağlıklı Kentler Birliği'nin kurulması 22.12.2004 tarihli 8226 sayılı Resmi Gazetede yayınlanmış, Birlik Tüzüğü de İçişleri Bakanlığı tarafından onaylanmış ve yürürlüğe girmiştir. ${ }^{6}$ Birliğin amacı ve görevleri; Sağlıklı kentleri ve aday kentleri bir araya getirmek, kentlerde sürdürülebilir gelişme, yönetim ve sosyal destek yaratmak, kent içi ve kentler arası eşitsizlikleri azaltmak, kentlerdeki yaşam alanlarının en iyi seviyeye ulaştırılması ve sürdürülebilir kalkınma ilkeleri doğrultusunda herkes için kaliteli bir yaşam sunmak, sağlıklı kentler yaratmak ve yaşatmaktır [34].

\footnotetext{
${ }^{4}$ http://www.skb.gov.tr/wp-content/uploads/2019/09/Bursa-Buyuksehir-Belediyesi-Sehir-Saglik-Profili-2019.pdf (ET:13.12.2020)

${ }^{5}$ Kentli Dergisi 14.Sayı, Ocak- Şubat- Mart 2014, Sağlıklı Şehir Planlaması ve Kentsel Tasarım, Bursa. https://silo.tips/download/salkl-ehir-planlamas-ve-kentsel-tasarm.html (ET:13.12.2020)

${ }^{6}$ https://www.resmigazete.gov.tr/eskiler/2004/12/20041222.htm (ET:13.12.2020)
} 
Türkiye'de "Sağlıklı Kentler" hareketinin gelişebilmesi, benimsenmesi ve uygulanabilmesi için Bursa Büyükşehir Belediyesi ülkemizde bu konuya önem veren kentleri bir araya getirerek Türkiye Sağlıklı Kentler Birliğini kurmuştur. Yalova, Van, Kadıköy, Afyon, Tepebaşı, Çankaya, Ürgüp, Ordu, Kırıkkale ve Bursa Büyükşehir Belediyeleri birliğe katılmak istediğini belirten meclis kararı almış ve 10 kurucu üye belediye ile kurulmuştur [57]. Bu kentlerden Van ve Afyon daha sonra birlikten ayrılmıştır (şekil $1)$.

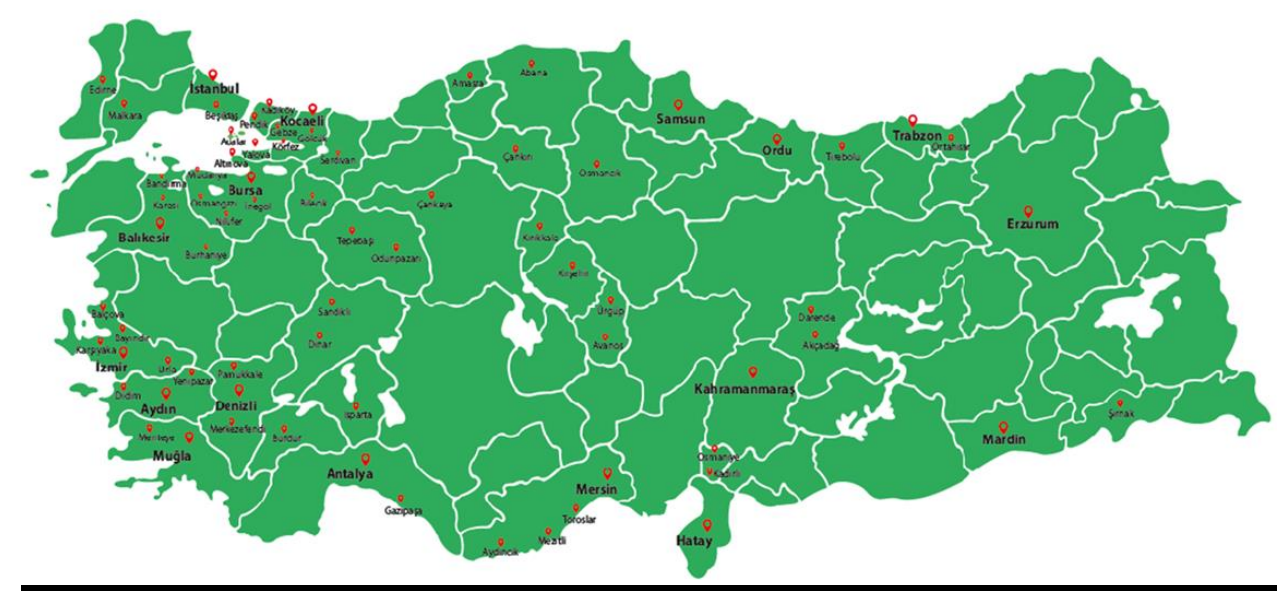

Şekil 1. Türkiye’ de ki Sağlıklı Kentler Birliği Üyesi Belediyeler (2019) (Türe C., Ar M., 2019).

Ülkemiz 4. Fazda Dünya Sağlıklı Kentler Birliği'ne dâhil olmuştur. 4., 5., 6., fazlar Türkiye'nin en aktif olduğu süreçlerdir. Sağlıklı Şehir Hareketinin en hızlı yayıldığı faz 4. Fazdır. Bursa, Aydın, Gölcük, Kadıköy, Yalova, İstanbul, Çankaya, Bartın, Avanos, Kırıkkale, Tepebaşı, Trabzon 4. fazın Türkiye'den üyeleridir. 4. fazda Sağlıkta etki Değerlendirilmesi, Sağlıklı Yaşlanma, Sağlıklı Şehir Planlaması ve Fiziksel Aktivite ve Aktif Yaşlanma konularına 4. fazda odaklanılmıştır. Ülkemizden de 12 şehrin yer aldığg fazda konularla ilgili çalışmalar yapmak ve proje üretmek görevi bulunmaktadır [60]. 5.Fazda tüm yerel sağlık politikalarında sağlık alanında eşitlik konusunu kabul ederek 'Önemseyen ve Destekleyici Çevreler', 'Sağlıklı Yaşam' ve 'Sağlıklı Kentsel Çevre ve Tasarım' temalarında çalışmalar anlatılmıştır [59]. 6. fazda ise halk sağlığının geliştirilmesi ve sağlık alanındaki eşitsizliklerin azaltılması' ve 'sağlık alanında liderlik ve katılımcı yönetişimin iyileştirilmesi' üzerinde çalışmalar planlanmıştır [58].

\section{BURSA KENTİ VE SAĞLIKLI KENTLER KAPSAMINDA YAPILAN BAZI PROJELERIN İRDELENMESI}

Bütün ülkelerin sağlıklı, güvenli ve refah içinde bir geleceğe sahip olması ancak küresel bir işbirliği ile mümkündür. DSÖ Sağlıklı Şehirler Ağı içindeki üye şehirlerle birlikte çözümü, WHO (DSÖ) Sağlıklı Şehirler Projesi bu işbirliğinin önemli bir örneğidir. Yaşanmış tecrübelerin paylaşılması, başarılı proje sonuçlarının aktarımı Bursa'da kent sağlığının geliştirilmesi açısından büyük fayda sağlamıştır [27]. Bursa, Türkiye'den Sağlıklı Şehirler Projesi'ne üyeliği kabul edilen ilk şehirdir. Bursa için amaç sağlıklı, çağdaş, sürdürülebilir, daha yeşil, tarihi ve geleneksel değerlerini daha iyi koruyan bir kent olmasıdır. Bu amaç doğrultusunda; sağlık, çevre, ulaşım, planlama, projeler, güvenlik ve sosyal çalışmaların temsil edildiği bir Sağlık Platformu oluşturulmuş ve Sağlık Gelişim Planı hazırlanmıştır. Bu planda Bursa'daki şehir sağlik seviyesini arttıran ve eşitsizlikleri azaltma amaçlı başlayan, devam eden, tamamlanan projeler ve programlar tanımlanmıştır [27]. Sağlıklı Kentler Birliği çalışmalarına örnek Bursa Büyükşehir Belediyesi uygulamaları verilebilir. Dünya Sağlık Örgütü tarafından başlatılmış olan Sağlıklı Kentler Projesi'ne çalışmaların başladığı yıllardan itibaren Avrupa'daki kentler gibi Türkiye'deki kentlerden birçok il ve ilçe belediyesi katılım ve destekleri ile katkıda bulunmuşlardır. Bursa Büyükşehir Belediyesi Dünya Sağlık Örgütü Sağlılı Kentler Ağı'na 3.Dönem (1998-2002) 2000 yılında Türkiye'den ilk kabul edilen kent olmuştur. Bursa Büyükşehir Belediyesi iyi örgütlenmiş ve 
etkin bir Sağlıklı Kentler Projesi'nin gelişimi ve yayılması için destek, öncülük, danışmanlık sağlamakta; ayrıca Dünya Sağlık Örgütü'nün Türkiye'deki ve Uluslararası çalışmalarında da oldukça aktif bir rol oynamaktadır [27]. Bursa İli Sağlıklı Kentler üye belediyelerin dahil olduğu yapılmış bazı plan ve projelerle ilgili bilgiler verilmiştir. İlgili projeler seçilirken daha çok mekânsal planlama ve kent sağlığına ilişkin üst ölçekli proje ve raporlar seçilmeye çalışılmıştır. (Tablo 4).

Tablo 4. Bursa ve üye belediyelerde yapılmış bazı plan ve projeler

\section{Bursa Sağlık Gelişim Planı}

Bursa Sağlık Gelişim Planı 2005 yılında hazırlanmıştır. Şehirde bazı programlar yapılıp şehir hakkında kararlar alınırken orada yaşayan insanların sağlık ve esenlik durumları göz önünde bulundurulmalı ve sağlığı daha iyi duruma getirme amaçlanmıştır. Geçmişine sahip çıkan ve yeniliklere açık bir yönetim anlayışı ile tüm çalışmalar; temiz çevresiyle, düzenli altyapısıyla, rahat ulaşımıyla, kültürel ve sosyal aktiviteleriyle, her yönden öncü, önde ve örnek bir şehir oluşturma yolunda gerçekleştirilmiştir. Dünya Sağlık Örgütü'nün yol göstericiliği ve desteğiyle daha da hız kazanmış Bursa şehri, modern ve sağlıklı bir şehir oluşturma yolunda yürürken, tüm vatandaşların yeme-içme, barınma, iş, sağlık, eşitlik ve güvenlik gibi ihtiyaçlarının karşılanmasını, yaşam alanlarının en iyi seviyeye ulaştırılmasını ve sürdürülebilir kalkınma ilkeleri doğrultusunda herkes için kaliteli bir yaşamı ilke edinmiştir [34].

Bursa Sağlık Profili çalışması ilk 2014 yılında hazırlanmış olup 2019'da yenilenmiştir. Çalışmada, kentin fiziksel, sosyo-ekonomik, çevresel ve kentsel altyapı göstergeleri ve Bursa'da yaşam göstergeleri detaylı olarak değerlendirilmiştir. Bursa kentinin sosyal, çevresel ve ekonomik sorunlarının çözümünde çeşitli göstergelerle bilimsel bir altyapı oluşturması amaçlanmıştır.

Sağlık Profili

Bursa Bursa Büyükşehir Belediyesi’nin sera gazı salımarını hesaplamak ve bir azaltım planı

Büyükşehir

Belediyesi

Íklim

Değişikliği

Eylem Planı

Bursa

Büyükşehir

Belediyesi ve

Bursa İli

Karbon Ayak

izi Envanteri oluşturmak üzere başlattığı "BURSA İklim Değişikliği Eylem Planı" (BİDEP) süreci iklim değişikliğinin tehdit ettiği geleceğe taşıyacak önemli bir adım niteliğindedir. Bu planlama ile "Temiz Enerji Kullanımı sağlayarak, küresel ısınmayı azaltmak, çevreyi korumak ve Türkiye'nin dünyadaki algısını değiştirmek" ve "katı atıkların farklı yöntemlerle enerjiye dönüştürülmesini sağlamak" amaçlanmıştır [51].

Karbondioksit cinsinden ölçülen ve bunların sera gazı miktarı altında insan faaliyetlerinin çevreye neden zararın ölçüsü olan karbon ayak izi; Bursa Büyükşsehir Belediyesi için kent ölçeğinde hesaplanmıştır. Bursa ölçeğinde konut, işyeri, otel, sanayi, tarım, okul, hastane, yol, sokak aydınlatma ve kamu binalarının elektrik tüketimleri, şehir içi ulaşımda kullanılan tüm araçların egzoz kullanımları, katı ve sıvı atık bertaraf envanteri Bursa ili karbon ayak izi hesaplanmıştır [52].

Nilüfer kenti sanayi tabanlı kent olup aynı zamanda kentsel hareketliliğinde fazla olduğu bir yerdir. Bu kentte düşük karbon salınımlı bir hayat yaratacak biçimde halkın davranış biçimlerini değiştirmek, yenilenebilir enerji kaynaklarının kullanımını teşvik etmek ve

Bursa Nilüfer

Belediyesi

Enerji Eylem Planı yaygınlaştırmak, kendi çalışmaları ve hedeflerinde de sürdürülebilir kentsel gelişmeyi hayata geçirmek gayesi ile planlar yapmak ve gerçekleştirmeyi Nilüfer Belediyesi görev edinmiştir. 2013 yılında hazırlanan bu çalışma yenilenebilir enerji kaynakları kullanımı ve enerji verimliliği konusunda kararlar almak ve projeler üretmek için Türkiye'ye örnek yeni bir yapılanma oluşturmuştur. Plan başkanlar sözleşmesi şeklinde oluşturulmuş, enerji kaynakları hesaplanmıştır. Nüfus yoğunluğu, konut dağılımları ve enerji tüketimleri yönüyle değerlendirilmiştir [53].

Proje kapsamında, Bursa gece gökyüzü parlaklığı ölçümleri yapılarak bölgenin 1şık kirliliği haritası çıkartılmış ve yanlış aydınlatmadan kaynaklanan enerji kaybı hesaplanmıştır. Türkiye'de ilk kez yapılmış projedir [54]. Kentleşme hareketindeki artış ile yaşam

Bursa İli Işık Kirliliği

Araştırma

Projesi Sonuç Raporu kalitesini yükseltme çabası beraberinde birçok çevre sorununu getirmektedir. Işık belirli seviyenin üzerinde kirliliğe dönüşerek, özellikle kentsel mekanlarda yaşamı olumsuz yönlerde etkilemektedir. Işı̆̆ın gün içindeki ve mevsimsel değişimleri dikkate alınarak konut alanından ticaret alanına kadar bütün alan kullanımları yönlendirilmelidir. Yoğun kentsel yapılaşmanın mevcut olduğu alanlarda bina yüzeyleri ve çatıların uygun plantasyon teknikleri ile bitkilendirilerek yansıyan ışığın önüne geçilmelidir ve kaldırım ve caddeler yeşil dokuya kavuşturulmalı, ışı̆̆ı yansıtan sert, parlak yapı yüzeylerine çok fazla yer verilmemelidir [13]. 
Kentlerin gelişmesi ile büyüyen sorunlara çözüm olarak Tablo 4'teki başlıklarda yer verilmiş olup öneri ve tespitler ile Sağlıklı Kent oluşumu açısından değerlendirme yapılabilir. Şehir Sağlık Profili oluşumu ile Bursa kentinin sosyal, çevresel ve ekonomik sorunlarının çözümüne altlık hazırlanmıştır. Kentteki hızlı nüfus artışı ile sorunların daha çok arttığı, iklim, sanayi, ulaşım, tarım alanları ve yapılan faaliyetler, kent güvenliği, doğal afetler, atık yönetimi, barınma, hastalık hali, sosyal faaliyetler gibi kent bileşenleri konularında önlemler alınarak izlenecek yol belirlenmiştir [41].

Çevre ve Şehircilik Bakanlığı'nın hazırladığı 2019 - 2022 Ulusal Akıllı Şehirler Stratejisi ve Eylem Planında yer alan Bursa İklim Değişikliği raporunda, kentte sera gazı salınımı hesaplanmış ve azaltmak için yapılacaklar belirlenmiştir. İklim değişikliği geleceği tehdit eden önemli bir konu olup Sağlıklı kentlerin oluşumunda sorun teşkil eder. Bu plan ile temiz enerji kullanımına teşvik etmek, kullanımı arttırmak, küresel ısınmayı azaltmak, hava kalitesinin artmasını sağlamak, çevreyi korumak ve katı atıkları farklı yöntemler ile kullanılabilir enerjiye dönüştürülmesi sağlanmıştır [42]. Kentteki karbon salınımı düşünülerek sürdürülebilir sağlıklı kentler oluşturmak için yenilenebilir enerji kaynaklarının kullanımına teşvik etmek ve yaygınlaştırmak, enerji kaynakları konusunda projeler geliştirilmesi öngörülmüş̧ür [52]. Işık kirliliği dünyada ve ülkemizde genel bir sorundur. Gelişmiş ülkelerde kirlilik düzeyi daha azdır. Ülkemizde de sorun fazla büyümeden müdahale edilip gökyüzü fazla aydınlanmadan korunabilir. Sağlık odaklı sürdürülebilir kentler oluşturulmasına yönelik stratejiler belirlenmeli, kentlerin sağl1k göstergeleri belirlenirken ışık kirliliğinin etkileri değerlendirilmeli ve bu kirliliğe sebep olan olumsuzluklara çözüm üretilmelidir [13].

\section{SAĞLIKLI KENTLER BíRLIĞINE ÜYE BELEDIYELERININ, SAĞLIKLI KENTLER BİRLİĞİ AÇISINDAN BAZI SORUN/FAYDALARININ ORTAYA KONULMASI}

Mahalli idare birliği olan sağlıklı kentler birliği yerel yönetimlerle işbirliği ve fikir paylaşımı içerisindedir. Yerel yönetimler kent sorun ve planları karar alma sürecinde il meclis üyelerinin ve kent konseylerinin katılımı ile konuyu sonuca bağlamaktadır. Kent Konseyleri Yönetmeliği 8/10/2006 tarihli ve 26313 sayısı ile Resmi Gazetede yayımlanıştır. ${ }^{7}$ Yurttaşların yönetime ve kararlara katılmaları açısından önemlidir. Merkezi yönetimin, yerel yönetimin, meslek ve sivil toplum kuruluşlarının, kent problemlerinin çözümlenmesinde, ortak aklın ve uzlaşmanın esas alındığı demokratik yapıları oluşturur. Kent konseyleri yerel yönetimlerle ne kadar bağlantılı, kararlara ne kadar dahil olabiliyorlar, kent sorumlulukları bilincine sahipler mi, kent sorunlarının bilincindeler mi vb. soruları cevaplanmalıdır. Kent sorunlarına hakim, yaşadığı kenti tanıyan, yerel yönetimlerle paylaşımcı- katılımcı olan, özgür demokratik olmalıdırlar. Karar mekanizmasının bir halkasını oluşturmaları sağlıklı kent kararlarında etki unsuru olduklarını göstermektedir [15].

Sağlıklı Kentler Birliği’nin temaları içerisinde Hakkaniyet, Sürdürülebilirlik, Halkın katılımı ve Sektörler arası işbirliği gibi ilkelerin uygulanması için gerekli olan düzenleme ve yasal zeminin varlığına ve desteğine rağmen; yönetsel, mali ve politik birçok nedenlerden dolayı istenilen hedeflere ulaşılması zorlaşmaktadır. Sağlıklı Kentler Birliği' nin belediyelerdeki proje birimlerinde az sayıda elemanın özveriyle çalışmasına rağmen belediyeler tarafından bu birimlere idari, mali ve yetki verilmemesi çalışmaların istenilen noktalara çıkmasını engellemektedir [15]. Projelerin yürütülmesinde uzman görüşü, yönetişim modeli, katılmanın farklı meslek gruplarından ve sektörler arası kişilerin kararlarının oluşturulması şeklinde bir ofis modeli gerekli olmaktadır. Uygulamada ise dar bir kadro ile genellikle sağlık sektöründen veya kent planlamacılarından oluşan Sağlıklı Kent Koordinatörü 'nün başkanlığındaki ofislerde yeterince uzman personel çalıştırılmamaktadır. Proje Ofislerinin sağlıklı kentler hareketine uygun olarak başarılı çalışmalarda bulunması için yeterli personele, kaynağa, sahip olduğu görev ve sorumluluk paralelinde, mali destek ve yetkilendirilmeye gereksinimi vardır [8].

\footnotetext{
${ }^{7}$ https://www.mevzuat.gov.tr/mevzuat?MevzuatNo=10687\&MevzuatTur=7\&MevzuatTertip=5 (ET: 13.12.2020)
} 
Kentlerdeki insan kaynaklı oluşmuş sorunların çözümü, yine o kentin bileşenleri paydaşları aracılığı ile insanın getirdiği önerilerle neticelenecektir. Sağlıklı Kentler Birliği sorunların tespitinde, bu sorunlara çözüm bulunmasında, fikir birliği-paylaşım gibi çok yönlü düşünceleri bir araya toplayıp kalıcı kararlar ve çözüm önerileri üretecektir. Yerel düzeyde Sağlıklı Kentler Birliğinde bulunmanın yararlarına değinildiğinde, sağlıklı olmak ile yaşanılan çevre arasında sıkı bir bağlantı vardır. Kişiyi tanımlayan yaşadığı çevre, toplum ve kenttir. Bireyin mutlu olması da yaşadığı kente kendini ait hissettiği, o çevreyi benimsediği kadardır. Bir kentte birey tüm imkânlara yeterince erişemiyorsa, işsiz ve ekonomik sıkıntıları varsa, sosyal faaliyetlerden yararlanamıyorsa, sağlık, barınma, ulaşım vb. günlük yaşamı oluşturan etmenlerden yeterince fayda sağlayamıyorsa yaşadığ $\mathrm{k}$ kent bireyi mutlu etmez, aitlik duygusu oluşmaz. Bu bağlamda Bursa kentinin Dünya Sağlık Örgütü (WHO) Sağlıklı Şehir Projesi'nde yer almasının bazı faydaları aşağıda sıralanmıştır.

- Kentte halk sağlığı konularında bilincin artması ve ilgili uluslararası hareketlerin bir parçası olmak,

- AB sürecinde uluslararası bir örgütün ve birliğin üyesi olmanın getirdiği avantajlar,

- Sağlık 21 ilkeleri ve uygulamaları içindeki "Herkes İçin Sağlık" hedefinde yerel çalışma olarak yer almak,

- İçinde etkin uygulamaların geliştirileceği uluslararası bir ortam oluşturmak,

- Ortaklık projeleri için Avrupa Birliği, Dünya Sağlık Örgütü, Avrupa Konseyi Sağlık Komisyonu fonu gibi ekstra finansal kaynaklar sağlamak,

- Bursa'da yapılacak örnek çalışma ile Türkiye'deki diğer kentlere örnek olmak,

- Türkiye'deki Sağlıklı Kentler Birliği çalışmalarını geliştirmek,

- Sağlik sorunları üzerine diğer üye şehirlerle bilgi ve uygulama deneyimi paylaşmak için bir ağ oluşturmak,

- Sağlık ve sağlıktaki hakça olmayan dağılımın sosyal etkileri ile ilgili araştırma ve geliştirmelere ulaşılması,

- Kentte bütün tarafların, kent için katılımcı ve demokratik çalışma kültürünü geliştirmeleri,

- Şehir Sağlık Gelişim Planı ile Bursa'da sağlı̆g ilgilendiren tüm sektörleri bir araya getirmek ve ortak projeler geliştirerek kaynak tasarrufu ve işbirliği sağlamaktır [27].

Yerel yönetimler kentlerin sorunlarının tespitinde bu sorunlara çözümler üretilmesinde etkin birimlerdir. Kentlerin alt yapısının oluşturulması, gelişim planlarının yapılması, ulaşım, sosyal faaliyetler gibi bütün hizmetlerin sağlanmasında önemli sorumluluk taşımaktadırlar. Yaşanabilir sağlıklı kentler ve bu kentlerde kaynakların verimli sürdürülebilir şekilde kullanılıp hizmetler sunulmalıdır. Sağlıklı kentler birliği yerelde sağlıklı yaşanabilir kentler oluşturma gayesi ile yerel yönetimlerin sorunlarına ortak olmuş, kentte yaşam kalitesinin arttırılması için öneriler geliştirmişlerdir. Kent yaşamını etkileyen her konuda bilinçlendirme, bilgilendirme yaparak farkındalık oluşturmuşlardır. Yerel yönetim çalışmalarına, bu çalışmaları ile katkı sağlamaları açısından aralarındaki ilişki önem arz etmektedir.

Sağlıklı Kentler Birliği üye belediyeler ile bilgi alışverişini gerçekleştirmek ve geliştirmek aynı zamanda sağlıklı kent proje ve deneyimlerini paylaşmak amacıyla genellikle meclis toplantılarını takip eden günlerde bakanlık yetkilileri, belediye başkanları, belediyelerdeki sağlıklı kentler ofis çalışanları, akademisyenler, sivil toplum örgütleri, diğer kamu/özel kesim temsilcileri ve geniş bir ilgili kitlesinin katılımı ile eğitim toplantıları düzenlemektedir. Bu bilgi paylaşımı birliğe üye belediyelerin kendi birimlerinde hazır bilgiyi kullanmalarını desteklemektedir.

\section{SONUC}

İnsanlar için şehirlerin değeri azalmak yerine daha çok artmakta, mevcut şehirler fiziksel olarak yeterli gelmemektedir. Kentler büyüdükçe kullanılabilir alanlar küçülmektedir. Kentte yaşayan nüfus kırsaldaki nüfus sayısını geçmiştir. Teknolojik yenilikler, gelişmiş sanayi, eğitim, iş olanakları, ekonomik ve sosyal firsatlar kırsaldaki insanı kente yönlendirmektedir. Kentteki hızlı nüfus artışı ile çevre sorunları da ortaya çıkmakta, kentleşmede zorluklar gerçekleşmektedir. Özellikle büyük kentlerde kirlilik (hava, su, kanalizasyon, atık), ulaşım kentteki imkânlara herkesin eşit erişememesi ile kentin yük 
altında kalma sebeplerini beraberinde getirmektedir. Kentlerdeki bu kontrolsüz nüfus büyümesi ekolojik dengeyi de bozmaktadır. Kentteki altyapı, barınma, imar sorunları, su kirliliği, ulaşım, katı atık, atık su, güvenlik, rekreasyonel yeşil alanların oluşturulması gibi birçok soruna yerel yönetimler çözüm üretmeye çalışmaktadır. Nüfusun hızlı artışı ile kontrol edilememe durumu oluşmaktadır. Sağlıklı Kentler Birliği yerel yönetimlerin başlattığı çalışmalara destek olmaktadır. Sağlıklı kent oluşumunda, bu sorunların çözüm aşamasında yerel yönetimlere destek vererek ileriki kent planlama aşamalarına altlıklar oluşturmaktadır.

Sağlıklı yaşamı, sağlıklı kent ve sağl1klı kentli için ekolojik fonksiyonlar, nesli tükenmekte olan türlerin kurtarılması, biyoçeşitlilik için daha iyi ortamlar oluşturulması, havayı ve diğer kirletici unsurları temizlemek, yürüyüş alanları oluşturmak, park ve rekreasyon alanları, spor alanları oluşturmak, kentli için sosyal ihtiyaç ve talepleri düşünmek, yeşil kentler oluşturmanın ve kentsel doğal peyzajın insan sağlığını ve refahını etkileyen unsurlar yerel yönetimlerin hizmet alanlarıdır.

Sağlıklı Kentler Birliği’nin çalışmaları il ve ilçe belediyelerinde sorunların belirlendiği, bu sorunlara çözüm önerileri getirildiği, farklı disiplinlerin bir araya gelerek kentle ilgili her şeyin araştırılıp deneyim ve fikirlerin birleştirilmesi ile sağlıklı kente ulaştırmayı kolaylaştırmak amacındadır. Bilgi alışverişinde bulunarak, sağlıklı çevre, huzurlu ve yaşanabilir kent, erişilebilir eşit imkânlar kent planlaması konularında çalışmalar yapılmaktadır.

Bütün ülkelerin sağlıklı, güvenli ve refah içinde bir geleceğe sahip olması ancak küresel bir işbirliği ile mümkündür. DSÖ Sağlıklı Şehirler Ağı içindeki üye şehirlerle birlikte çözümü, Dünya Sağlı Örgütü Sağlıklı Şehirler Projesi bu işbirliğinin önemli bir örneğidir. Yaşanmış tecrübelerin paylaşılması, başarılı proje sonuçlarının aktarımı, Bursa'da kent sağlığının geliştirilmesi açısından büyük fayda sağlamıştır. Dünya Sağlık Örgütüne göre sağlık, sadece hastalık hali değil, fiziksel, ruhsal ve toplumsal olarak tam iyilik halidir. Sağlıklı Kentler birliği çalışmalarını bu tanım doğrultusuna yapmayı hedefleyip sürdürmektedir. Bursa kentinin Sağlıklı Kent olması için yapılan birçok örnek çalışma vardır. Hazırlanan 'Kent Sağlık Profili"' ile kentin fiziksel, sosyo-ekonomik, çevresel ve kentsel altyapı göstergeleri ve Bursa' da yaşam göstergeleri detaylı olarak değerlendirilmiştir. Kentsel yaşamın gidişatı ve insanların bu gidişatta güçlendirilmesi, kentsel halk sağlığı sorunlarıyla mücadele, insana yönelik sağlı hizmetlerinin arttırılması ve desteklenmesi gibi yaşam kalitesini yükseltmeyi amaçlayan çalışmalar ile ülkedeki diğer belediyelere örnek oluşturmaktadır.

Bursa iline ilişkin yapılan çalışmalar incelendiğinde gelişmeler kaydedilen bazı konular aşağıdaki gibi özetlenebilir [6].

- Kentleşmenin ortaya çıkardığı sorunların çözümünde sağlıklı kentin bir çözüm unsuru olması

- Sağlıklı kent kavramı, sağlıklı kent ilke ve değerleri, kentleşme ve kentleşmenin ortaya çıkardığı çevre ve sağlık sorunlarının çözümünde önemli olması

- Sağlıklı kente ilişkin çalışmaların kentsel hayat ve kentsel karar alma süreçlerine katılımı sağlamas1,

- Sağlıklı kent çalışmaları ile halkın katılabileceği yeni yol ve yöntemlerin kullanılabileceği katılımcı demokrasi modelleri hayata geçirilmektedir. Bu kapsamda kadınlar, çocuklar, yaşlılar, engelliler ve yoksullar gibi dezavantajlı olan grupların karar alma sürecine katılımı ve sorunlarına çözüm odaklı yaklaşmak imkânı sağlanmış olmaktadır.

- Sağlıklı kent çalışmaları ile kentin planlı ve sürdürülebilir olması desteklenmektedir.

- Sürdürülebilir kalkınma ve çevre kavramları ile doğrudan ilgili olan tarihi ve kültürel mirasa sahip çıkılması sağlanmaktadır.

- Yönetişim ilkelerinden biri olan hesap verilebilirlik kavramı sağlıklı kentin özellikle katılım kavramı ile bütünleşen ve bireylerin katılımını kolaylaştıran bir kavram olarak ortaya çıkmaktadır

- Sağlıklı kent çalışmaları, kentte yaşayanlar için yaşanabilir bir kent oluşturmasını desteklemektedir. 
Sonuç olarak Sağlıklı Kentler, sağlıklı bir toplum için gereklidir. Gerek merkezi gerekse yerel yönetimler tarafindan bütüncül bir yönetim anlayışıyla hayata geçirilmelidir.

Not: Bu çalışma ‘Sağlıklı Kentler ve Yerel Yönetim İlişkisi; Bursa Büyükşsehir Örneği’ isimli Yüksek Lisans Tezi kapsamında hazırlanmıştır.

TEȘEKKÜR: Bu çalışma Düzce Üniversitesi Bilimsel Araştırma Projeleri tarafından desteklenmiştir (Proje no: 2012.05.01.001).

\section{KAYNAKLAR}

[1] D. Ak, D. Bıçkı, "Yavaş kent (Cittaslow) hareketinin kentsel yaşam kalitesi bağlamında değerlendirilmesi," Uluslararast Sosyal Araştırmalar Dergisi, c. 9, s. 46, 2016.

[2] M. M. Akkan, "Akıllı kent uygulamaları ve Konya örneği,” Yüksek lisans tezi, Siyaset Bilimi ve Kamu Yönetimi Ana Bilim Dal1, Sosyal Bilimler Enstitüsü, Necmettin Erbakan Üniversitesi, Konya, Türkiye, 2019.

[3] M. Aksoğan, M. Çalış Duman, "Akıllı şehir uygulamaları; Malatya örneği smart city applıcatıons; Malatya example,' 1. Uluslararası Battalgazi Multi Disipliner Çalışmalar Kongresi, c. I, Malatya, Türkiye, 2018.

[4] A. At11, B. Gülgün, İ. Yörük, "Sürdürülebilir Kentler ve Peyzaj Mimarlığ1," Ege Üniversitesi Ziraat Fak. Derg., c. 42, s. 2, ss. 215-226, 2005.

[5] H. A. Aydın, Ö. Çamur, "Kentsel dönüşüm uygulamalarında başarılı dünya örnekleri: Danbara, Solidere, Rio De Janeiro," Kahramanmaraş Sütçü İmam Üniversitesi İ.I.B.F. Dergisi, c. 6, s. 1, 2016.

[6] A. Belli, "Türkiye'de sağlıklı kentler ve büyükşehir belediyeleri üzerine karşılaştırmalı bir analiz," Uluslararası Toplum Araştırmaları Dergisi, c. 10, s. 17, Kahramanmaraş, Türkiye, 2019.

[7] İ. Başaran, "Sağlıklı kent planlaması açısından Isparta," Doktora tezi, Sosyal Bilimler Enstitüsü, Dokuz Eylül Üniversitesi, İzmir, Türkiye, 2008.

[8] İ. Başaran, "Sağlıklı kentler kavramının gelişiminde sağlıklı kentler projesi," Dokuz Eylül Üniversitesi Sosyal Bilimler Enstitüsü Dergisi, c. 9, s. 3, 2007.

[9] E. Bıçakçığlu, "Belediye birlikleri ve Türk dünyası belediyeler birliği," Yüksek lisans tezi, Mahalli İdareler ve Yerinden Yönetim Bölümü, Kamu Yönetimi Anabilim Dalı, Sosyal Bilimler Enstitüsü, Marmara Üniversitesi, İstanbul, Türkiye, 2010.

[10] Y. Boz, T. Çay, "Şehri Akıllı yapan özellikler ve dünyada öne çıkan akıllı şehirler," Tmmob 6. Coğrafi Bilgi Sistemleri Kongresi, Ankara, Türkiye, 23-25 Ekim 2019.

[11] N. Cavilla, S. Kahlmeier ve F. Racioppi, "Avrupa'da Fiziksel Aktivite ve Aktif Yaşam," Türkiye, 2006.

[12] M. Çetin, Ç. Çiftçi, "Literatüre göre dünya ve ülkemizden örneklerle akıllı kent kavramının irdelenmesi," Türkiye Ulusal Çevre Bilimleri Araştırma Dergisi, c. 2, s. 3, ss. 134-143, 2019.

[13] N. Demircioğlu Yıldız, H. Yılmaz, "Işık kirliliği, ortaya çıkardığı sorunlar ve çözüm önerileri," Atatürk Üniversitesi Ziraat Fak. Derg., c. 36, s. 1, ss. 117-123, 2005. 
[14] Anonim. (2014, 22-25 Ekim). Dünya Sağllk Örgütü Uluslararası Sağglklı Şehirler Konferansı [Çevrimiçi]. Erişim: http://www.skb.gov.tr/wp-content/uploads/2014/12/DS\%C3\%96-Atina-Raporu2014.pdf

[15] H. Erkul, T. Baykal, H. Kara, "Kent konseylerinin sorunları üzerine bir inceleme: Çanakkale kent konseyi örneği," Mustafa Kemal Üniversitesi Sosyal Bilimler Enstitüsü Dergisi, c. 10, s. 22, ss. 85$105,2013$.

[16] O. Gürsoy, "Akıllı kent yaklaşımı ve Türkiye'deki büyükşehirler için uygulama imkânları," Yüksek lisans tezi, Kamu Yönetimi Bölümü, Siyaset Bilimi ve Kamu Yönetimi Anabilim Dalı, Sosyal Bilimler Enstitüsü, Hacettepe Üniversitesi Ankara, 2019.

[17] İTÜ Vakfı. (2017, Temmuz). Akıllı Şehirler [Çevrimiçi]. Erişim: https://www.ituvakif.org.tr/dergi/sayi_77.pdf

[18] A. Karahan Özkur, "Dirençli kentler bağlamında Karaman kentinin değerlendirilmesi," Yüksek Lisans Tezi, Peyzaj Mimarlığı Anabilim Dalı, Fen Bilimleri Enstitüsü, Ankara Üniversitesi, Ankara, Türkiye, 2018.

[19] Sağlıklı Kentler Birliği. (2014, Mart). Sağlıklı Şehir Planlaması ve Kentsel Tasarım [Çevrimiçi]. Erişim: https://silo.tips/download/salkl-ehir-planlamas-ve-kentsel-tasarm

[20] E. Meriç, "Sağlığı geliştirme açısından sağl1klı kentler projesi," Yüksek lisans dönem projesi, Kamu Yönetimi Anabilim Dalı, Ankara Üniversitesi, 2006.

[21] S. G. Meydan Yıldız, "Çevre bilinci ve eko-kent planlaması: Gölbaşı özel çevre koruma bölgesi örneği," Doktora Tezi, Sosyal Çevre Bilimleri Anabilim Dalı, Sosyal Bilimler Enstitüsü, Ankara Üniversitesi, Ankara, Türkiye, 2016.

[22] S. A. Mirghaemi, “Akıllı kentler üzerine bir inceleme: Türkiye örneği,” Yüksek lisans tezi, Fen Bilimleri Enstitüsü, İstanbul Aydın Üniversitesi, İstanbul, Türkiye, 2019.

[23] G. Nair, "Kentsel yaşamın bilgi ve iletişim teknolojilerinin 1şı̆̆ı̆nda yeniden inşası ve Anadolu'dan bir örnek: Sivas Belediyesi'nin akıllı kent uygulamaları," Manas Sosyal Araştırmalar Dergisi, c. 8, s. 1, ss. 521-540, 2018.

[24] Özel İhtisas Komisyonu, “On Birinci Kalkınma Planı,” T. C. Kalkınma Bakanlığı, Türkiye, 2018.

[25] A. Özcan, Ekolojik temele dayalı sürdürülebilir kentsel gelişme: Malatya kent örneği üzerinden bir değerlendirme [Çevrimiçi]. Erişim: https://www.ayk.gov.tr/wpcontent/uploads/2015/01/\%C3\%96ZCAN-Ay\%C5\%9Fe-EKOLOJ\%C4\%B0K-TEMELE-DAYALIS\%C3\%9CRD\%C3\%9CR\%C3\%9CLEB\%C4\%B0L\%C4\%B0R-KENTSELGEL\%C4\%B0\%C5\%9EME-MALATYA-KENT-\%C3\%96RNE\%C4\%9E\%C4\%B0\%C3\%9CZER\%C4\%B0NDEN-B\%C4\%B0R-DE\%C4\%9EERLEND\%C4\%B0RME.pdf

[26] D. Özdemir Şengül, “Türkiye'de mahalli idare birlikleri," Yüksek lisans tezi, Kamu Yönetimi Bilim Dalı, Sosyal Bilimler Enstitüsü, Selçuk Üniversitesi, Konya, Türkiye, 2008.

[27] Bursa Büyükşehir Belediyesi Sağlıklı Şehirler Proje Koordinatörlüğü. (2005). Sağllklı Bursa İçin Vizyon ve Planlarımız [Çevrimiçi]. https://www.bursa.bel.tr/dosyalar/vizyon_ve_planlarimiz_trk_02_aralik_2005.pdf 
[28] M. A. Sevim, İ. Kırcova, E. Çuhadar, "Yerel Yönetimlerde Akıllı Şehir Vizyonu: Şehir Yönetim Araçları Ve Trendleri," Strategic Public Management Journal, s. 9, ss. 109-126, 2019.

[29] H. Tek Turan, "5355 Sayılı Yasaya Göre Türkiye'de Birlikler: Hizmet Sunumunda Adem-i Merkeziyetçi ve Katılımcı Yaklaşım," Strategic Public Management Journal (SPMJ), c. 1, s. 2, ss. 72 $87,2015$.

[30] Z. Toprak, (2012). Türkiye'de Yerel Yönetimler-Yapılanma Merkez-Yerel Yönetim İlişkileri [Çevrimiçi].

Erișim: https://kisi.deu.edu.tr/zerrin.toprak/TURKIYE'DE\%20YEREL\%20YONETIMLER\%20YAPILANM A.pdf. Erişim Tarihi: 27.12.2020.

[31] A. Uçar, S. Şemşit, N. Negiz, "Avrupa Birliği akıllı kent uygulamaları ve Türkiye'deki yansımaları," Süleyman Demirel Üniversitesi İktisadi ve İdari Bilimler Fakültesi Dergisi, c. 22, s. Kayfor15 Özel Sayıs1, ss. 1785-1798, 2017.

[32] B. Uzun, "Türkiye'de yerel yönetim birlikleri: Türkiye Belediyeler Birliği ve Tarihi Kentler Birliği örnek incelemeleri," Siyaset Bilimi ve Kamu Yönetimi (Kent ve Çevre Bilimleri) Anabilim Dalı, Sosyal Bilimler Enstitüsü, Ankara Üniversitesi, Ankara, Türkiye, 2012.

[33] E. Yalçın, "Küresel kente alternatif olarak sakin şehir: Türkiye sakin şehirleri üzerinden değerlendirme," Sosyal Ekonomik Araştırmalar Dergisi, c. 19, s. 38, 2019.

[34] A. N. Fidan, J. Alan, E. Güniçen. (2017). Sağllklı Bursa İçin Vizyonumuz ve Planlarımız [Çevrimiçi]. Erişim: http://www.skb.gov.tr/wp-content/uploads/2017/12/Bursa-Buyuksehir-

Belediyesi.pdf

[35] Kahramanmaraş Büyükşehir Belediyesi. (2019, 29 Mart). Akıllı Şehirler Kahramanmaraş [Çevrimiçi]. Erişim: https://kahramanmaras.bel.tr/fs/dosyalar/akilli_sehir_kahramanmaras_katalog.pdf

[36] B. Kavcar. (2017, 28 Şubat). Eko-kent Kent Modeli [Çevrimiç̧i]. Erişim: http://sbpturkiye.com/eko-kent-modeli.html

[37] Cittaslow Türkiye. (2014). Başka Bir Dünya Mümkün [Çevrimiçi]. Erişim: https://cittaslowturkiye.org/

[38] World Healty Organization. (2020, 02 Şubat). Countries. [Çevrimiçi]. Erişim: https://www.who.int/countries

[39] Türkiye Belediyeler Birliği. (2005, 29 Eylül). Mahalli İdare Birlikleri. [Çevrimiçi]. Erişim: https://www.tbb.gov.tr/belediyelerimiz/mahalli-idare-birlikleri/

[40] Mahalle İdare Birlikleri Kanunu, T.C. Resmi Gazete, s. 25842, 26 May1s 2005.

[41] Türkiye Sağlıklı Kentler Birliği. (2020, 23 Mart). Sunumlar. [Çevrimiçi]. Erişim: http://www.skb.gov.tr/kategori/sunumlar/

[42] Coğrafi Bilgi Sistemleri Genel Müdürlüğü. (2019, Mart). Akıllı Şehirler Beyaz Bülteni. [Çevrimiçi].

Erișim: https://webdosya.csb.gov.tr/db/cbs/menu/akillisehirlerkitap_20190311022214_20190313032959.pdf

[43] Birleşmiş Kentler ve Yerel Yönetimler Orta Doğu ve Batı Asya Bölge Teşkilatı. (2020, 10 Aralık). [Çevrimiçi]. Erişim: http://uclgmewa.org/ak\%C4\%B111\%C4\%B1-\%C5\%9Fehir-gaziantep/ 
[44] F. Yalım, "Yavaş Şehir (Cittaslow) Hareketi Ekseninde Kent markalaşması ve Kent İletişimi: Kırklareli Vize Yavaş Şehir Örneği," Trakya Üniversitesi İktisadi ve İdari Bilimler Fakültesi Dergisi, c. 6 , s. 2, ss. 1-28, 2018.

[45] Healty World News. (2020, 13 Aralık). Dünya Sağlık Örgütü Sağlıklı Şehirler Projesi ve Aşamaları ile Türkiye (1987-2020) [Çevrimiçi]. Erişim: https://www.healthworldnews.net/dunyasaglik-orgutu-saglikli-sehirler-projesi-ve-asamalari-ile-turkiye-1987-2020/

[46] Çevre Şehircilik Bakanlığı. (2016). İklime Dirençli Kentler [Çevrimiçi]. Erişim: http://www.ipa.gov.tr/assets/uploads/files/climate_change_261217.pdf

[47] Ş. G. Eren, “Tokyo: Solaris-Güneş İmparatorluğu'nun Dirençli, Kırılgan ve Tehlikeli Kenti,” Kent Araştırmaları Dergisi, c. 10, s. 28, ss. 907-941, 2019.

[48] Türkiye Sağlıklı Kentler Birliği, "Sağlıklı Kentler İçin Yenilenebilir Enerji,” Sağlıklı Kentler Birliği Mersin Konferansi, 2016.

[49] Smart City Kayseri. (2019). Akıllı Şehircilik Çalıştayı [Çevrimiçi]. Erişim: https://www.smartcitykayseri.com/akilli-sehircilik-calistayi

[50] Bursa Büyükşehir Belediyesi. (2018). Akıllı Şehir Yolunda Bursa [Çevrimiçi]. Erişim: http://akillisehir.bursa.bel.tr/

[51] Bursa Büyükşehir Belediyesi. (2017). Bursa Sürdürülebilir Enerji ve İklim Değişikliği Uyum Planı [Çevrimiçi]. Erişim: https://www.bursa.bel.tr/dosyalar/bursa_busecap_2017.pdf

[52] Bursa Büyükşehir Belediyesi. (2015, 28 Haziran). Bursa'nın Karbon Ayak İzi Belirleniyor [Çevrimiçi]. Erişim: https://www.bursa.bel.tr/bursanin-karbon-ayak-izi-belirleniyor/haber/19733

[53] Nilüfer Belediyesi. (2018, 30 Mart). Sürdürülebilir Enerji Eylem Planı İzleme [Çevrimiçi]. Erişim: http://www.nilufer.bel.tr/dosya_yoneticisi/enerjieylem2.pdf

[54] Bursa Büyükşehir Belediyesi. (2020, Mart). Bursa İli Işılk Kirliliği Araştırma Projesi Sonuç Raporu [Çevrimiçi]. Erişim: http://www.skb.gov.tr/wp-content/uploads/2020/07/Bursa-BIKARaporu.pdf

[55] 5393 Belediye Kanunu, T.C. Resmi Gazete, s. 25874, 3 Temmuz 2005.

[56] Türkiye Belediyeler Birliği. (2014, 23 Haziran). 6360 Sayılı On Dört İlde Büyükşehir Belediyesi ve Yirmi Yedi İlçe Kurulması ile Bazı Kanun ve Kanun Hükmünde Kararnamelerde Değişiklik Yapılmasına Dair Kanuna İlişkin Rehber [Çevrimiçi]. Erişim:

https://www.tbb.gov.tr/storage/userfiles/rehber_ve_bilgi_notlari/6360_torba_personel_rehber.pdf

[57] Sağl1klı Kentler Birliği. (2004). Birlik Tüzüğü. [Çevrimiçi]. Erişim:

http://www.skb.gov.tr/birlik-hakkinda/tuzuk/

[58] World Healty Organization. (2015, Kasım). DSÖ Avrupa Sağlıklı Şehirler A $\breve{g} \iota$ 6. Faz (20142018) Hedefler ve Şartlar [Çevrimiçi]. Erişim: http://www.skb.gov.tr/wpcontent/uploads/2015/11/DSO-Avrupa-Saglikli-Sehirler-Agi-6.-Faz-Rehberi.pdf

[59] Sağlıklı Kentler Birliği. (2015, 24 Kasım). Sağlıklı Şehirler Hareketi [Çevrimiçi]. Erişim: http://www.skb.gov.tr/saglikli-sehirler-hareketi-s13520k/

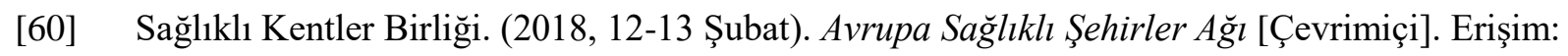
http://www.skb.gov.tr/dunya-saglik-orgutu-avrupa-saglikli-sehirler-agi/ 
[61] İstanbul Büyükşehir Belediyesi. (2017, 1-2 Ağustos). Sürdürülebilir Akıllı Şehirler Çalıştayı Bilgi Kitapçı̆̆l [Çevrimiç̧i]. Eriş̧im:

https://recturkey.files.wordpress.com/2017/08/surdurulebilirakillisehirlercalistayi_kitapcik_vf.pdf

[62] Yenipazar Belediyesi. (2020, 14 Temmuz). Sağlıklı Kent [Çevrimiçi]. Erişim:

https://yenipazar.bel.tr/?s=sa\%C4\%9F1\%C4\%B1kl\%C4\%B1+kent

[63] Newsweek. (2019). World's Smartest Cities - The Newsweek Momentum Awards [Çevrimiçi]. Erişim: https://www.newsweek.com/momentum-awards-worlds-smartest-cities

[64] E. Sandalcı. (2018, 1 Kasım). Dünyadan Akıllı Şehir Örnekleri [Çevrimiçi]. Erişim: https://magg4.com/dunyadan-akilli-sehir-ornekleri/

[65] Anonim. (2012, 7 Kasım). Akıllı Şehirlere Dünyadan Örnekler. [Çevrimiçi]. Erişim: https://www.ekoyapidergisi.org/186-akilli-sehirlere-dunyadan-ornekler.html

[66] Anonim. (1 Ekim 2021). Smart Dubai 2021 [Çevrimiçi]. Erişim: https://2021.smartdubai.ae/

[67] İstanbul Büyükşehir Belediyesi. (2019, 29 Aralık). İstanbul Akıllı Şehir Projesi Çevre Odak Alanı Çalıştayı [Çevrimiçi]. Erişim: https://www.isbak.istanbul/istanbul-akilli-sehir-projesi-cevreodak-alani-calistayi-gerceklestirildi/ 